\title{
Surgical management of congenital foetal hydrocephalus in a crossbred cow
}

Citation: Dangi, P., Ruhil, S., Singh, H., Samdhyan, A. and Potliya, S. 2021. Surgical management of congenital foetal hydrocephalus in a crossbred cow. J. Vet. Anim. Sci. 52(2): 180-182.

DOI: https://doi.org/10.51966/jvas.2021.52.2.180-182

Received: 08.04.2021

Accepted: 01.05.2021

Published: 01.06.2021

\begin{abstract}
A rare case of dystocia due to external congenital hydrocephalic foetus with ankylosis of forelimbs managed by ventral midline surgical approach in a crossbred cow is reported.
\end{abstract}

Keywords: Dystocia, hydrocephalus, monster.

Dystocia caused by various congenital foetal malformations have been reported in bovines and remains a challenging case especially for the field veterinarians due to the relatively lesser exposure that they have to such case presentations (Singh et al., 2003, Singh et al., 2013). Among the various congenital malformations, hydrocephalus occurs sporadically with an incidence of only 0.15 per cent in bovines (Long, 2001). Congenital hydrocephalus is a dropsical condition which may involve either the ventricles or the sub-arachnoid space of the brain (Noakes, 2009). This condition usually leads to foetal cause of dystocia at calving, causing economic loss to livestock farmers. Hence, the present study reports a rare congenital malformation diagnosed as foetal hydrocephalus in a crossbred cow. The aim of the current study is to disseminate knowledge about the morphology, diagnosis and successful management of congenital foetal hydrocephalus.

A pleuriparous full term crossbred cow was presented to the TVCC, LUVAS, Karnal for treatment of dystocia with the history of continuous straining and ruptured water bags nearly 12 hours before. On general clinical examination, the cow was dull and exhausted while clinical parameters were within the normal range. Per-vaginal examination revealed a fully dilated cervix with a foetus in anterior longitudinal presentation and dorso-sacral position. Detailed morphologic examination of the foetus revealed an enlarged head with a marked fluctuating swelling over frontal and occipital region with softening of cranial bones and without any foetal reflex, resting on ankylosed extended forelimbs. Ankylosis of the limbs could also have contributed to dystocia. The case was diagnosed as dystocia due to congenital foetal hydrocephalus. The cow was stabilized with supportive therapy

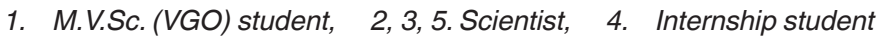

*Corresponding author email: hsinghvet@gmail.com

Copyright: (C) $2021 \mathrm{P}$. Dangi et al. This is an open access article distributed under the terms of the Creative Commons Attribution 4.0 International License (http://creativecommons.org/licenses/by/4.0/), which permits unrestricted use, distribution, and reproduction in any medium, provided the original author and source are credited.

180 Surgical management of congenital foetal hydrocephalus in... 
consisting of Inj. Calcium borogluconate $400 \mathrm{ml}$ slow intravenous, Inj. Ceftiofur sodium $2.2 \mathrm{mg} /$ kg body weight, intramuscularly; Inj. Flunixin meglumine $15 \mathrm{ml}$, intramuscularly; fluid therapy, rumenotorics and vitamin B-complex injection. Under epidural anaesthesia using $2 \%$ lignocaine, per vaginal delivery was attempted. The birth canal was well lubricated with the liquid paraffin. An incision was made by a guarded knife on the swollen foetal head to drain the fluid present in the cranial cavity. Per-vaginal delivery of the foetus was attempted by gentle traction but was not sucessful. Caesarean section was performed by ventral mid line approach following the standard procedure (Schultz et al., 2008) and a dead hydrocephalic male foetus was delivered (Fig. 1). Dissection of foetal head revealed the presence of strawcoloured fluid in sub-arachnoid space, affirming that the foetus was malformed and congenital external hydrocephalus was also confirmed. The cow was discharged on same day after with appropriate suggestions for follow up with a protocol consisting of antibiotics, antiinflammatory, rumenotorics, anti-histaminics and multivitamins all accompanied by a laxative diet for the next five days. The incision line and suture healed at 12 days after surgery and the cow showed an uneventful recovery after 15 days of surgery (Agerholm et al., 2015).

There are many factors which may be responsible for the accumulation of abnormal volume of the cerebrospinal fluid in the brain tissues such as possible intra-uterine infection of the foetus by viral agents like bovine viral

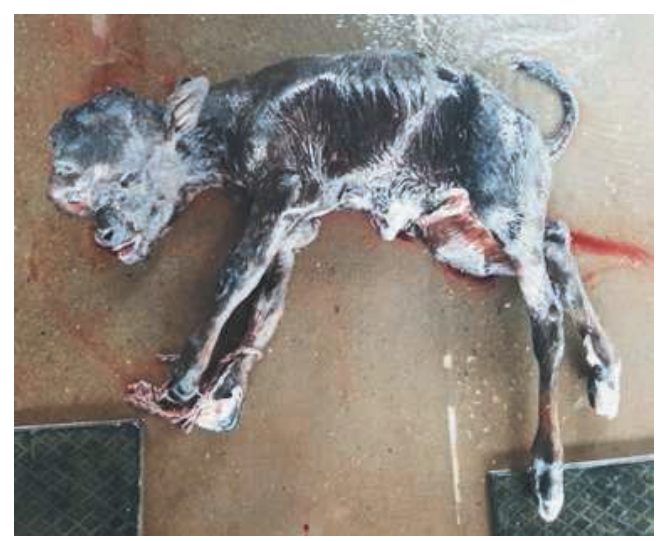

Fig.1: Hydrocephalic foetus delivered by caesarean section. diarrhoea virus (Agerholm et al., 2015) or this condition may also be due to the inheritance of a single autosomal recessive dominant gene with incomplete penetrance (Jabb and Kennedy, 1970; Purohit et al., 2012). Other predisposing factors for this malformation may include deficiency of vitamin-A or any other brain lesions that may cause a disturbance in the normal flow as well as the reabsorption of the cerebrospinal fluid (Ferris et al., 2011). The present case reported that congenital external hydrocephalus was morphologically characterized by a large sac containing serous fluid, hanging over the head and face. Similar observations have also been made earlier in cattle (Balasubramanian et al., 1997; Sunil et al., 2016; Saini et al., 2019) and buffalo (Dhaliwal et al., 1998) calves. It has also been documented that this type of congenital malformation is usually accompanied by lesions of the musculoskeletal system (Agerholm et al., 2015) as evidenced in the present study as well. In severe cases of hydrocephalus, caesarean section is recommended because it is very difficult to relieve dystocia by mutation and forced traction (Selvaraju et al., 2020).

The cause of death in hydrocephalic foeti may be due to pressure necrosis of the vital centres of the brain (Purohit et al., 2012). If the hydrocephalic calf is born alive, the chances of long term survival are very low because of various lesions in the central nervous system. Congenital malformations involving central nervous system and musculoskeletal system are comparatively easier to diagnose when the foetus is in an anterior longitudinal presentation.

\section{Acknowledgments}

The authors acknowledge the support of the Regional Director, HPVK, LUVAS, Uchani, Karnal for providing the necessary facilities.

\section{References}

Agerholm, J.S., Hewicker-Trautwein, M., Peperkamp, K. and Windsor, P.A 2015. Virus-induced congenital malformations in cattle. Acta Veterinaria Scandinavica. 57: 1-14. 
Balasubramanian, S., Ashokan, S.A., Seshagiri, V.N. and Pattabiraman, S.R. 1997. Congenital internal hydrocephalus in a calf. Indian Vet. J. 74: 446-447.

Dahliwal, G.S., Prabhakar, S., Vashista, N.K. and Sharma, R.D. 1998. Dystocia in a buffalo due to hydrocephalic fetus-a case report. Livestock Adviser. 13: 4041.

Ferris, R.A., Sonnis, J., Webb, B., Lindholm, A. and Hassel, D. 2011. Hydrocephalus in an American miniature horse foal: $A$ case Report and Review. J. Equine Vet. Sci. 31: 611- 614 .

Jabb, K.V.F. and Kennedy, P.C. 1970. Pathology of domestic animals ( $\left.2^{\text {nd }} \mathrm{ed}\right)$, Academic Press, NYC, $184 \mathrm{p}$.

Long, 2001. Abnormal development of the conceptus and its consequences. In: Arthur's Veterinary Reproduction and Obsterics. (8 ${ }^{\text {th }}$ edn), W.B. Soundars Co., Philadelphia, USA 141 p.

Noakes, D.E. 2009. Arthur's Veterinary Reproduction and Obstetrics, (8 $\left.{ }^{\text {th }} \mathrm{ed}\right)$. W.B. Saunder's Comp., Philadelphia, USA.

Purohit G.N., Kumar P., Solanki K., et al. 2012. Perspectives of fetal dystocia in cattle and buffalo. Veterinary Science Development. 2: 31-42.
Saini, R., Sharma, S.K., Aziz, P.R., Mir, L.A. and Pooniya, R. 2019. Congenital hydrocephalus in a calf and its surgical treatment: a case report. Ind. J. Vet. Sci. Biotech. 15: 81-82.

Schultz, L.G., Tyler, J.W., Moll, H. D. and Constantinescu, G. M. 2008. Surgical approaches for caesarean section in cattle. The Canadian Vet. J.. 49: 565.

Selvaraju, M., Parthasarathy, N., Varudharajan, V., Prakash, S. and Ravikumar, K. 2020. Dystocia due to Hydrocephalic Fetus in a Jersey Crossbred Cow. Int. J. Curr. Microbio. App. Sci. 9: 1029-1032.

Singh, H., Luthra R.A. and Gaudi, G. 2003. Dystocia due to hydrallantois and foetal ascites in buffalo. Intas Polivet. 4: 183185.

Singh, H., Gupta, G., Jan, M.H., Nab, S.U., Singh, J. and Dey, S. 2013. Atypical cyclopia in a buffalo calf. Buffalo Bull. 32 : 15-17.

Sunil, T.P., Vikram, R., Chaudhary, G.R., Nayanakumara, S.R., Kumar, A., Balamurugan, B., Kharayat, N.S ., Suthar A., Sanjukumar B.S. and Sagar, M. A. 2016. Dystocia in cattle due to hydrocephalic fetus concurrent with brachygnathism and ankylosed limbs: A case report. Int. J. Sci. Environ. Technol. 5: 1275-78. 